\title{
Impacts of Landfill on Groundwater Quality in Eligbolo-Eliozu, Obio/Akpor Local Government Area, Rivers State, Nigeria
}

\author{
${ }^{1}$ Ogbonna, V.A, ${ }^{2}$ Nwankwoala, H.O, ${ }^{1}$ Lawal, O \\ ${ }^{I}$ Department of Geography and Environmental Management, University of Port Harcourt, Nigeria \\ ${ }^{2}$ Department of Geology, Faculty of Science, University of Port Harcourt, Nigeria
}

\begin{abstract}
This study aims at assessing the impact of landfill on groundwater quality in Eligbolo-Eliozu, Port Harcourt, Nigeria. The lateral and vertical flow of waste contamination on soil and groundwater quality was examined using Wenner Array 2-D resistivity imaging. Two high dominants of leachate and gas zones were identified on profile one of 2-D resistivity imaging, two groundwater flow directions was identified, flowing downward to the southern direction of the state, from the West and East parts of the dumpsite. Leachate and gas infiltrate into the subsurface at the depth ranging from $4.91 \mathrm{~m}$ to $14.9 \mathrm{~m}$. Waste gasses such as carbondioxide and ammonia were dominant in the landfill, stunting the growth of toxic substances. The concentration of leachate percolates down from the dumpsite with time, and it is dominant on the soil surface than groundwater. The 2-D resistivity image result of all the profiles indicated that groundwater and soil in the vicinity of the landfill have been contaminated by leachate and waste gases (probably $\mathrm{CO}_{2}, \mathrm{CH}_{4}, \mathrm{NH}_{4}, \mathrm{HS}_{2}$, and $\mathrm{SO}_{2}$ ), with resistivity varying from $0.180 \Omega \mathrm{m}$ to $428 \Omega \mathrm{m}$ and $125 \Omega \mathrm{m}$ to $2844 \Omega \mathrm{m}$, respectively. This dominated the lateral layer and moving towards the groundwater table at the depth of $11.9 \mathrm{~m}$. The leachate plume penetrated side by side on profile 2 and the lateral layers of the landfill. Profiles 3 and 5 of the resistivity values of $256 \Omega \mathrm{m}$ and $290 \Omega \mathrm{m}$ were low due to waste gas diffusion on groundwater. Urgent attention in site planning, design and application of waste management regulation with continuous monitoring and assessment of soil and groundwater is recommended.
\end{abstract}

Keywords: Landfill, leachate, resistivity, groundwater quality, contamination, waste

\section{INTRODUCTION}

Over the years, the impacts of indiscriminate disposal of wastes on the landfill, has created substantial environmental damages especially, on human and natural resources. In Rivers state, the disposal of waste on landfills has been contracted out by some industrial companies to private individuals who purchases land (borrow pit) from rural areas and disposed off waste, without sorting out hazardous wastes from non- hazardous, assessing the soil porosity and permeability, groundwater depth, etc. This is attributed to demographic factors such as uncontrolled lifestyle, behaviour, the economic factors, demand and, to some extent, government policies (Lawal, 2014). This has led to uncontrolled production and disposal of waste on land and water that degrades the ecological balance and ecosystem stability. This method or practice is common to the developing countries where GNP is low with poor budget on waste management.

Landfill demands proper planning, design and management to stunt leaching contaminants into the soil. Ehirim \& Itota, (2013) opines that landfill contaminants find their way easier in a porous soil. That is to say, humid regions, especially the Niger Deltas of Nigeria where soils are porous with shallow aquifer are not refractory for the bioaccumulation of waste contaminants. Landfill has been identified as one of the major anthropogenic activities that have contributed to the pollution of the environment, because of the production of biogases and leachate. As Nigeria population geometrically increases, especially, in urban areas, the wastes generated are disposed indiscriminately on the rural lands, without proper planning and design of landfills.

Wastes such as solid including hazardous, non-hazardous, mixed, and radioactive materials are disposed-off on landfills without proper sorting, considering the residents health's in the study area. Sometimes, the waste leachate and gases generated has some hazardous properties that injects man and natural resources when exposed and / or takes some doses of these contaminants such as trace metals that causes cancer, liver and kidney disease, ulcer, gastrointestinal disease, high blood pressure 
Ogbonna, V.A et al. "Impacts of Landfill on Groundwater Quality in Eligbolo-Eliozu, Obio/Akpor Local Government Area, Rivers State, Nigeria"

(HBP), respiratory tracts, deficiency in the brain cell and other cells, heart disease, nervous system damage, etc., through consumption of water and agricultural products. According to UNICEF (2010), lack of potable water, sanitation and good hygiene claims the lives of an estimated 1.5 million children under the ages of five each year. Safe water is a major component of good health. Though, some wastes, when disposed lacks decomposition even when buried deep in the ground for a period of 20 to 30 years, while some are highly reactive toxic or monomers such as nitrogen mustard, epoxy, ethylene, polymers and plastics that contains plasticizers forms leachate (Asthana, 2012).

Dumpsites emit obnoxious odours and smoke that causes sickness to residents close to waste dumpsites. It was also noted that the residents whose houses are less than 200 meters from the dumpsite are victims of malaria, chest pains, cholera, and diarrhoeal (Salam, 2010). However, residents whose houses are more than 200 meters are also affected with the chest pain and Airborne chemical contamination such as gas particles and dust chemicals can be active during site operation. Disease carriers such as rats, flies etc., Conveyed waste contracted to neighbour hoods. That is to say, wet waste decomposes faster and as well releases a bad odour that negatively affects the landfills dwellers.

Waste disposed of at the dump sites produces pollution and later contaminates the natural environment through solid, liquid and gaseous waste pollutants. Solid and Liquid waste yields liquid substances while gaseous waste produces odour. Under certain hydrological conditions, leachate plumes and waste gases can move considerable distances and degrade ground water throughout wide areas. Based on this, the Government of Nigeria with a population of over 160 million people should invest heavily on borehole Projects throughout the Country to satisfy the geometric growth of the populace in regard to clean water demand and access to $99 \%$ quality health of average Nigeria. Without applying proper landfill management policy program that will help to prevent leachate plume infiltration into the soil and groundwater qualities, the health problem will surface at regular time interval.

In Rivers State, the method applied in disposal and management of waste generated in Obio/Akpor municipality is haphazard and uncoordinated. Managing waste requires adequate attention and application of up to-date management strategies basically, on solid waste management policy which is a leeway to waste free environment and good health. Therefore, this study is aimed at evaluating the impact of wastes on groundwater in the area.

\section{THE STUDY AREA}

The Eligbolo-Eliozu community is located in Obio/Akpor Local Government Area between latitudes $4^{\circ} 45^{\prime} \mathrm{N}$ and $4^{\circ} 60^{\prime} \mathrm{N}$ and longitudes $6^{\circ} 50^{\prime} \mathrm{E}$ and $8^{\circ} 00^{\prime} \mathrm{E}$ in the Niger Delta of Nigeria. The dump site is about $0.22 \mathrm{~km}$ away from G.U Ake Road, formerly known as Olu-Obasanjo By-Pass (Eliozu) and $2.72 \mathrm{~km}$ away from Rumuokoro junction. Figure 1 is the map of Obio/Akpor Local Government Area showing the study area.

The study area is located on sedimentary basin of the Southern Part of Nigeria with topography configuration that have evolved from the sedimentary patterns of the last 75,000 years as reported by Allen, sited in Oyegun, (1999). It consists of accumulations of cretaceous and tertiary sediments that are influenced by gravitational instability and tectonic forces (Oyegun, 1999). The general surface feature of the Area is very unique. The areas fall within the coastal belt on the sedimentary environment that corresponds lithologically to the Agbada, Akata, and Benin formations from earliest to recent of the modern Niger Delta. The soils in the region are mainly sandy-loams, humus, alluvium and outer belt of salt water swamps, clay and mud. The soils are rich in phosphorus because of nutrients from the volcanic parents' materials.

The sands are fine, coarse grained, unconsolidated and granular in texture. The depth to the usable aquifer in the area is approximately $30 \mathrm{~m}-45 \mathrm{~m}$, which is penetrated by most burials in the vicinity of the dumpsite (Ehirim et al., , 2009). The vegetation found is thick mangrove forest, raffia palms, and light rainforest, due to drainage pattern. It also drains both fresh and salt water. The salt water is caused by intrusion of sea water inland (Oyegun, 1999). 
Ogbonna, V.A et al. "Impacts of Landfill on Groundwater Quality in Eligbolo-Eliozu, Obio/Akpor Local Government Area, Rivers State, Nigeria"

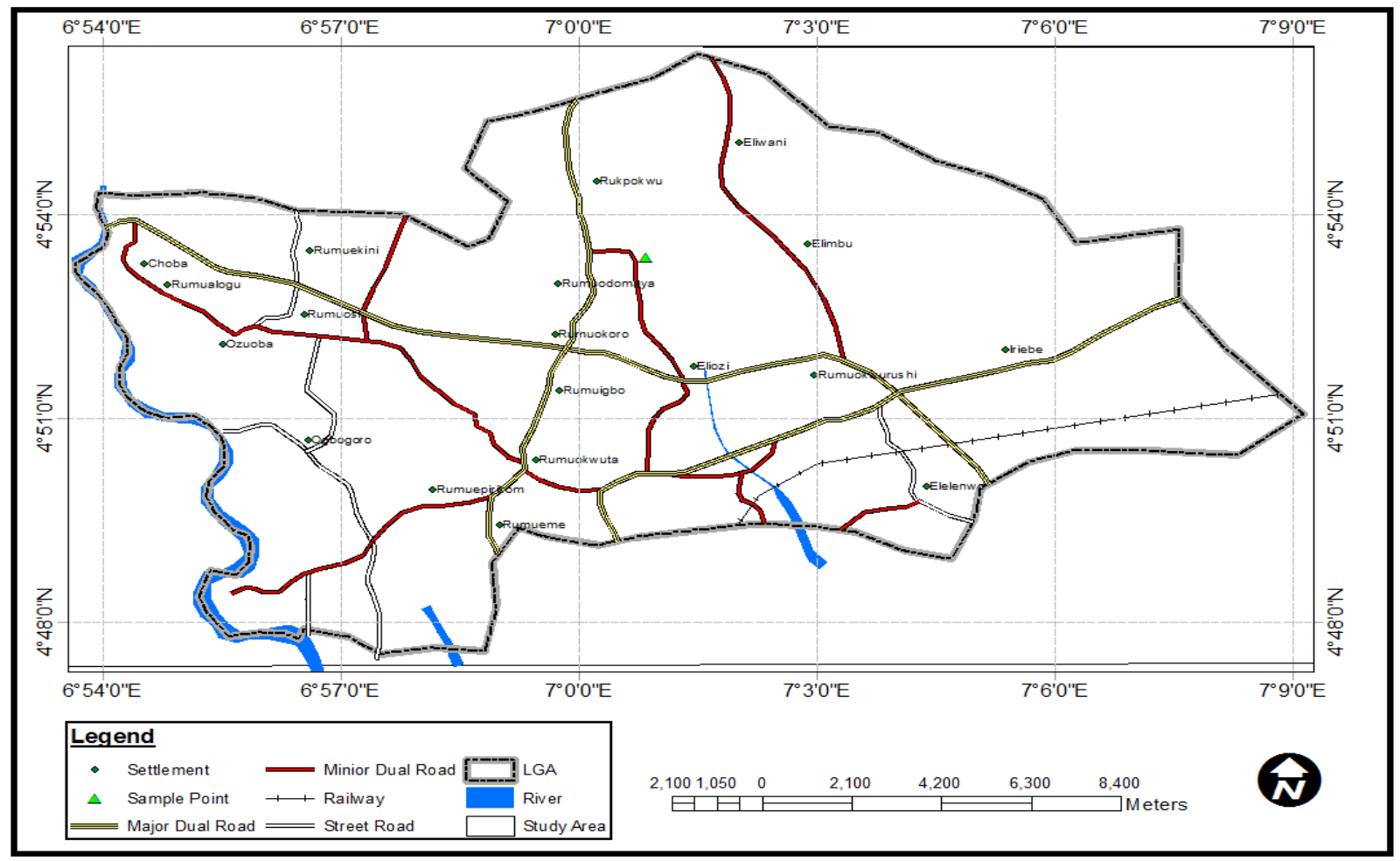

Fig1. Obio/Apkor LGA locating the study Area.

\section{METHOD OF STUDY}

A digital readout ABEM Terrameter SAS (Signal Averaging System) 300C was employed, using the Werner- $\alpha$ electrode configuration, and 2-D pseudo section. The Global Positioning System (GPS) was used to take co-ordinates of the study area and the sampled collection points. The Wenner array was used in assessing the impact of pollutants on the soil and groundwater quality in 2-Dimensional axis with 4-Point Test electrodes. Vertical Electrical Sounding (VES) was used for Geophysical investigation of soil medium which comprises soil layers, strength, and waste pollution on soil and groundwater qualities, etc. Two different imaging used in the assessment are Schlumberger Array 3-D and Wenner Array 2-D.

(I) Schlumberger array was used in assessing the potential effect of pollution and natural phenomena on the land surface and beneath in 3-Dimensions such as vertical, horizontal and lateral axis.

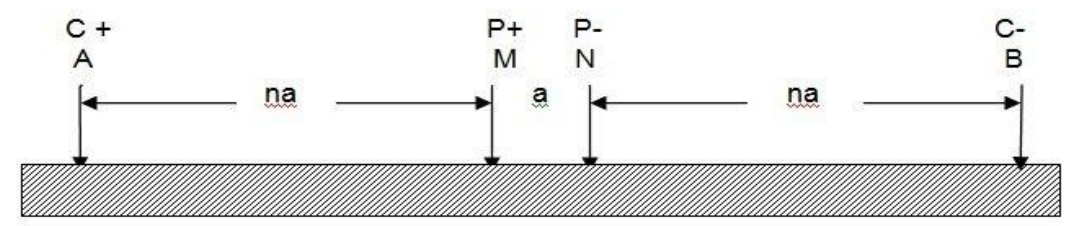

Figure2a. Schlumberger Array Electrode Arrangement (Land instrument and John, 1986-98).

(II) Werner-Array is also a combination of the 2-D pseudo section.

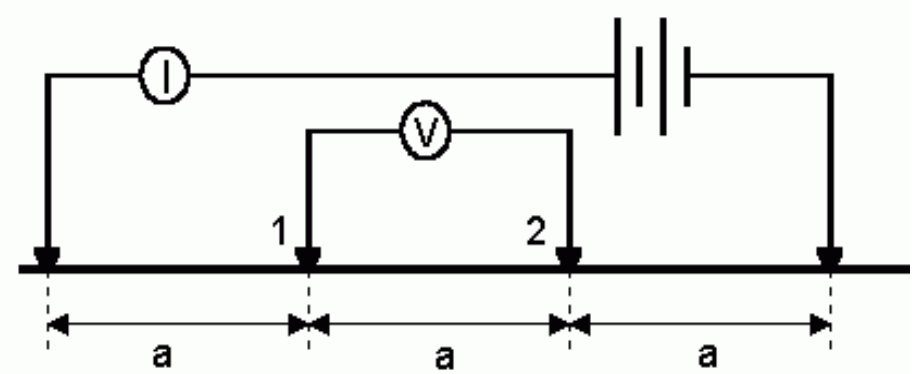

Figure2b. The Wenner Array Electrode Arrangement (E and S, 1984) 
Ogbonna, V.A et al. "Impacts of Landfill on Groundwater Quality in Eligbolo-Eliozu, Obio/Akpor Local Government Area, Rivers State, Nigeria"

\section{2-D Electrical Survey Measurements}

The resistance values obtained was converted into apparent resistivity values using the equation:

$\rho \mathrm{a}=2 \pi \mathrm{aR}$

Where $\mathrm{a}=$ Electrode spacing,

$\mathrm{R}=$ Resistance of the ground.

The resulting $\rho \mathrm{a}(\Omega \mathrm{m})$ were recorded in a recording sheet for subsequent processing and interpretation.

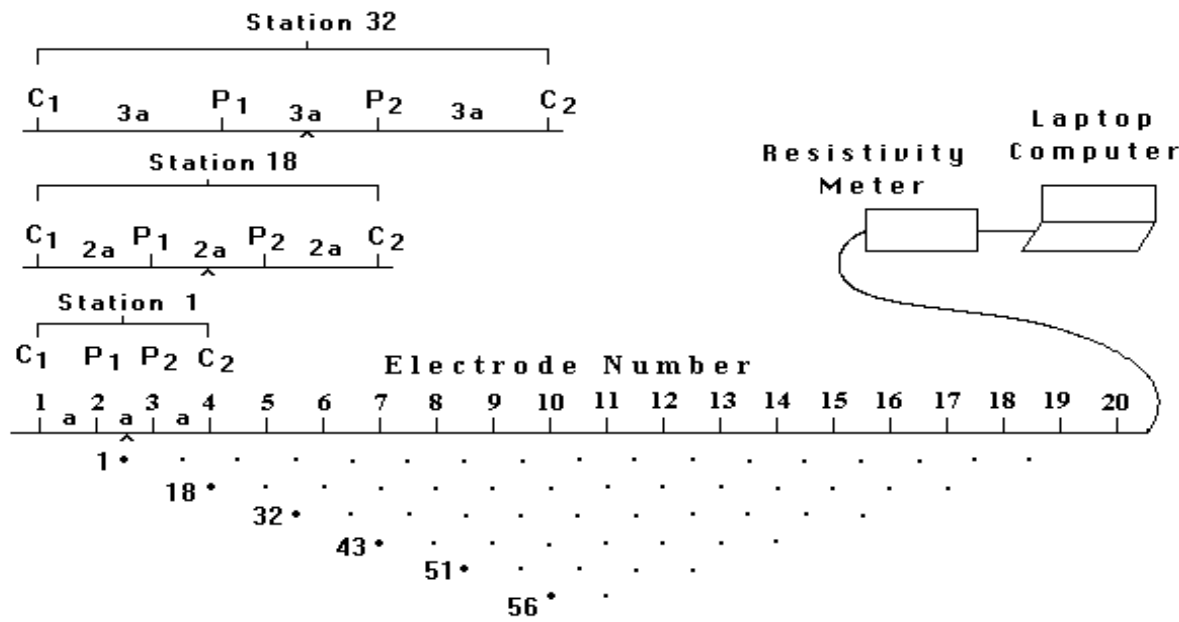

Figure3. The arrangement of electrodes for a 2-D electrical survey and measurements used to build up a pseudo-section (Loke, 1999).

$\mathrm{C}_{1}, \mathrm{C}_{2}=$ Current Electrode

$\mathrm{p}_{1}, \mathrm{p}_{2}=$ Potential electrode

$\mathrm{a}=$ Electrode sounding

$\mathrm{n}=$ Apparent depth for spacing $\mathrm{n} \& \mathrm{a}$

According to Loke (1999), the values of the apparent resistivities, electrode spacing and the xlocations were entered in a text file for processing, using RES2DIV inversion software. The iteration process continued until the RMS error between the measured and calculated apparent resistivity was minimized. The pseudo-section image of apparent resistivity serves as a means of portraying the measured field values. In each image, the horizontal $(\mathrm{X})$ axis represents the distance $(\mathrm{m})$ along the surface and also spacing between electrodes while the vertical $(Y)$ axis represents the depth (m). Colour legends at the bottom of the image indicate either apparent resistivity or subsurface resistivity values.

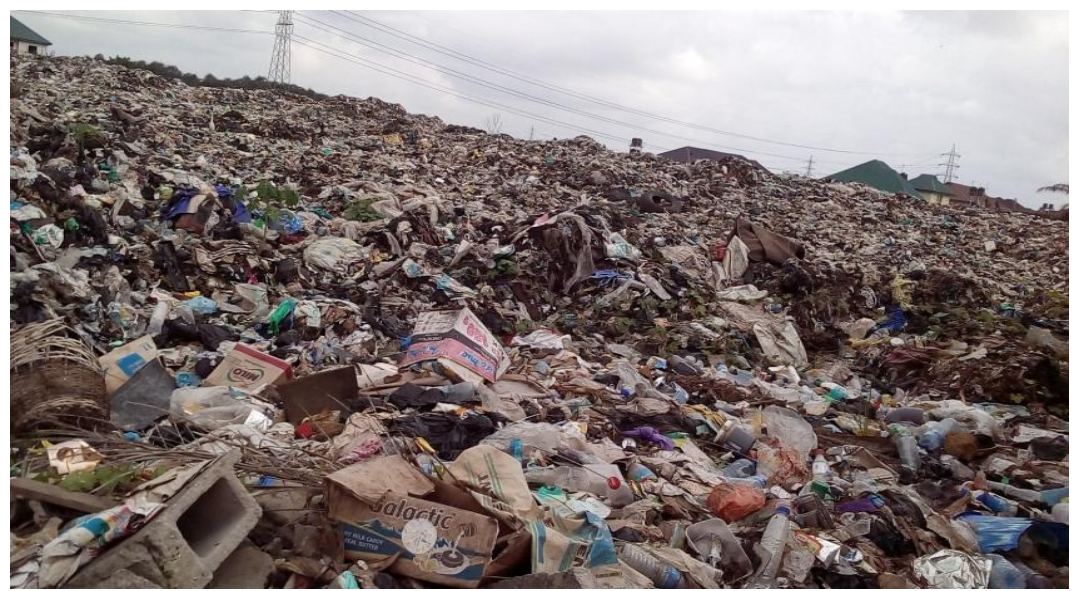

Figure5. Eligbolo-Eliozu Landfill Site 
Ogbonna, V.A et al. "Impacts of Landfill on Groundwater Quality in Eligbolo-Eliozu, Obio/Akpor Local Government Area, Rivers State, Nigeria"

\section{RESULTS AND DISCUSSION}

The determination of the vertical and lateral Flow pattern of waste contaminant around the landfill

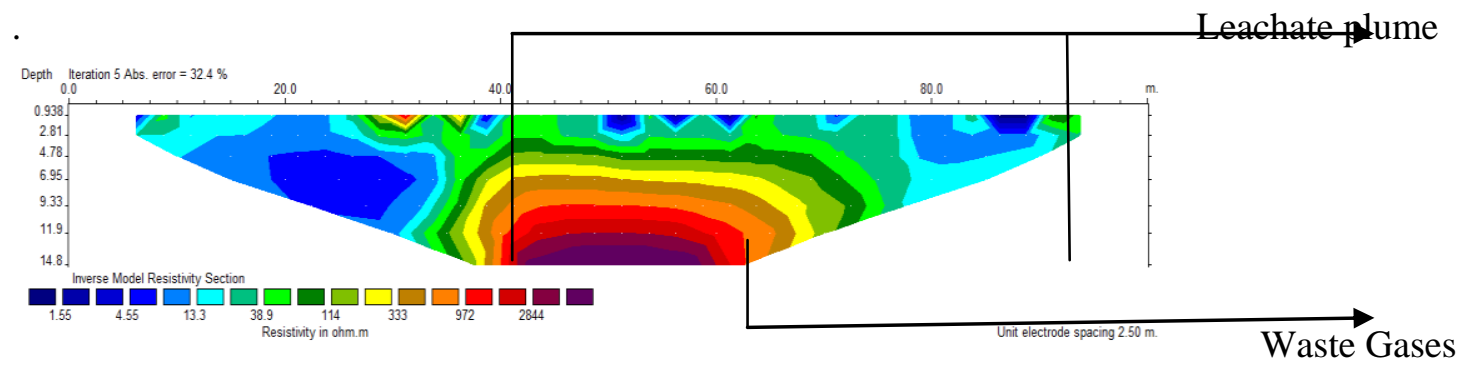

Fig6a. Inverse model Resistivity section along profile 1

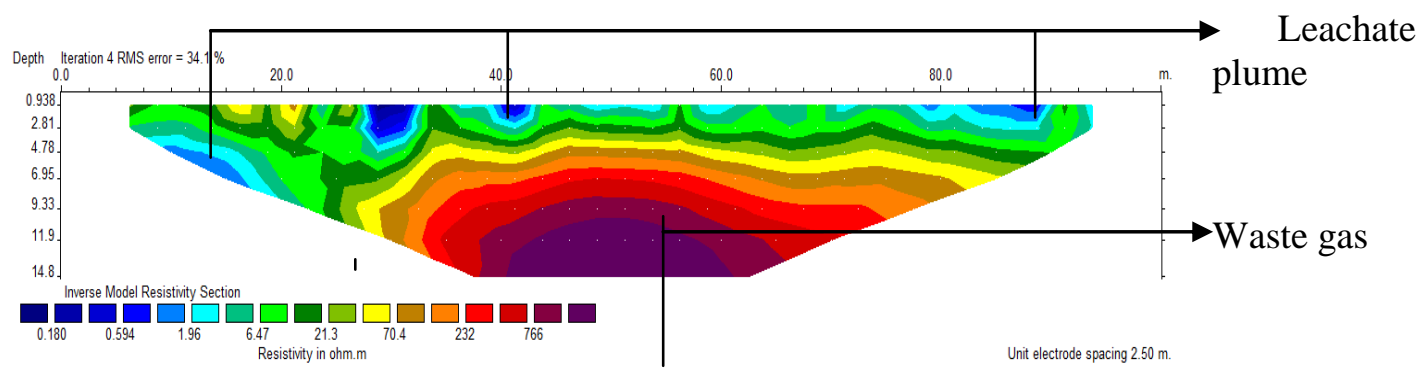

Fig6b. Inverse model Resistivity section along profile2
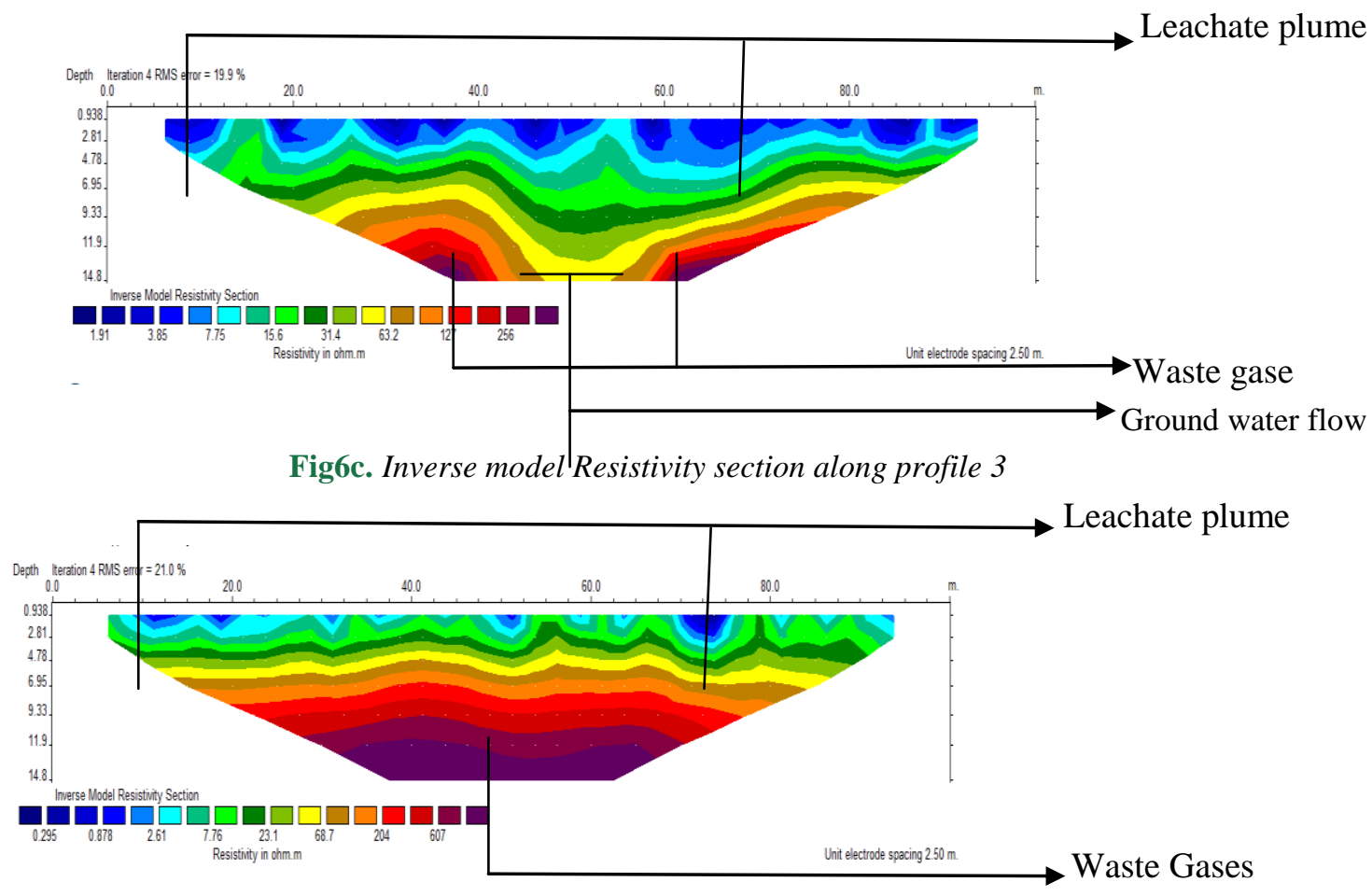

Fig6d. Inverse model Resistivity section along profile 4

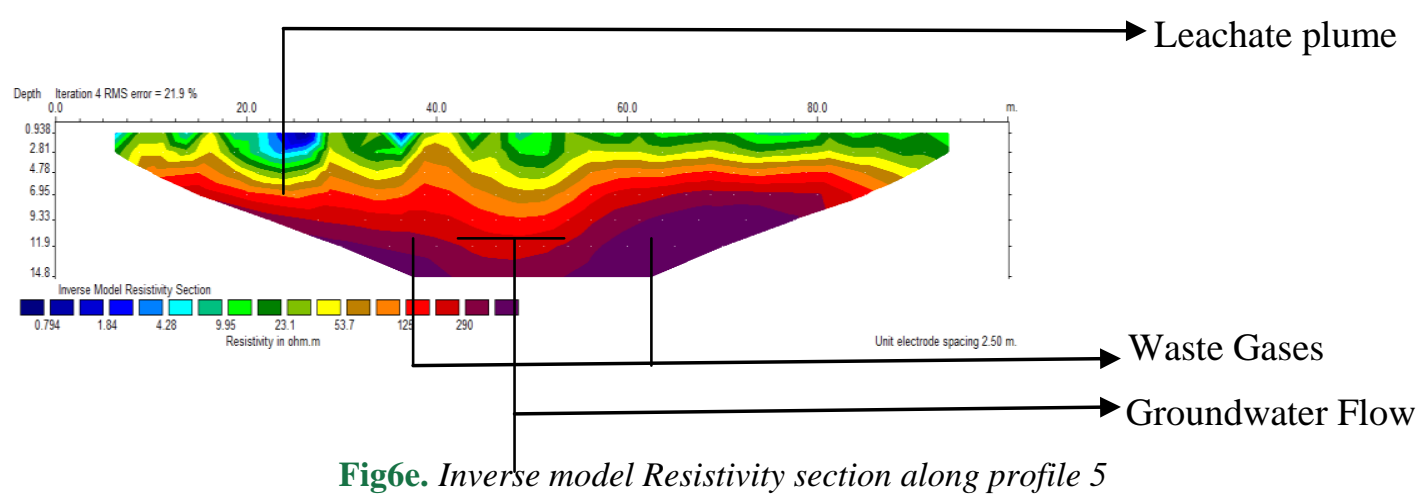

International Journal of Emerging Engineering Research and Technology V5 • I1 • January 2017 
Ogbonna, V.A et al. "Impacts of Landfill on Groundwater Quality in Eligbolo-Eliozu, Obio/Akpor Local Government Area, Rivers State, Nigeria"

\section{INTERPRETATION/DISCUSSION OF THE INVERTED RESISTIVITY PROFILES}

\section{Profile 1}

The profile lies 10m away from the edge of the landfill at the South/ East direction along community road. These traverse delineated two dominants low and high resistivity anomalies (Fig. 6a). The resistivity with low zone colours (Dark-Light Blue) $\leq 1.56 \Omega \mathrm{m}$ are isolated at the top surface of the profile, with surface point ranges from $0.0 \mathrm{~m}$ to $40 \mathrm{~m}, 48.9 \mathrm{~m}$ to $57.5 \mathrm{~m}, 60 \mathrm{~m}$ to $62.5 \mathrm{~m}, 70 \mathrm{~m}$ to $72.5 \mathrm{~m}$ and $77.5 \mathrm{~m}$ to $90 \mathrm{~m}$, at the depths of $2.81 \mathrm{~m} 11.9 \mathrm{~m}$ at North/West direction and $0.938 \mathrm{~m}$ to $9.38 \mathrm{~m} \mathrm{~N} / \mathrm{E}$ direction of the profile is identified as leachate plume. The (light green to yellow) colour with resistivity ranging from $38.9 \Omega \mathrm{m}$ to $333 \Omega \mathrm{m}$ at the depth of $0.938 \mathrm{~m}$ to $6.95 \mathrm{~m}$ with the surface points of $7.5 \mathrm{~m}$ to $10 \mathrm{~m}, 27.5 \mathrm{~m}$ to $37.5 \mathrm{~m}, 57.5 \mathrm{~m}$ to $60 \mathrm{~m}, 62.5 \mathrm{~m}$ to $67.5 \mathrm{~m}, 72.5 \mathrm{~m}$ to $76.8 \mathrm{~m}$ and $90 \mathrm{~m}$ to $92.5 \mathrm{~m}$, respectively, were also mapped and identified as porous and permeable sandy layers of varying grain sizes and moisture contents. Two anomalously high resistivity zones (Brown- Purple) are isolated at the top sections of the profile with resistivities varying from $333 \Omega \mathrm{m}$ to $\geq 2844 \Omega \mathrm{m}$ at the depth of $9.38 \mathrm{~m}$ to $14.8 \mathrm{~m}$ was identified as landfill gases such as (Methane, Ammonia, carbon (IV) oxides or sulphur (IV) oxides) which could be due to Anaerobic decomposition of the waste dump. The gases have been displaced in various layers of the soil on the site and it is as a result of low densities and pressure that is built up within the waste dump.

\section{Profile 2}

The profile lies $10 \mathrm{~m}$ away from the edge of the waste dump at North/East along community road. Two dominants low and high anomalous zones were delineated (Fig. 6b). The low resistivity anomaly (dark-light Blue) $0.180 \Omega \mathrm{m}$ to $1.96 \Omega \mathrm{m}$ is isolated at the top section of the profile, with the most prominent surface point ranges from $27.5 \mathrm{~m}$ to $32.5 \mathrm{~m}$, and $38 \mathrm{~m}$ to $90 \mathrm{~m}$, at the depth of $2.81 \mathrm{~m}$ and $6.95 \mathrm{~m}$ is identified as leachate plume. The (light green to yellow) colour with resistivity ranging from $0.180 \Omega \mathrm{m}$ to $1.96 \Omega \mathrm{m}$ at the depth of $2.81 \mathrm{~m}$ to $6.95 \mathrm{~m}$ with surface points ranging from $0.0 \mathrm{~m}$ to $32.5 \mathrm{~m}$ to $35 \mathrm{~m}$, and $90 \mathrm{~m}$ to $92.5 \mathrm{~m}$ respectively, mapped out and identified as porous and permeable sandy layers of varying grain sizes and moisture contents. Two anomalously high resistivity zones (Brown- Purple) are isolated at the top sections of the profile with resistivities varying from $232 \Omega \mathrm{m}$ to $\geq 766 \Omega \mathrm{m}$ at the depth of $6.95 \mathrm{~m}$ to $14.8 \mathrm{~m}$ was identified as landfill gases (Methane, Ammonia, carbon (IV) oxides or sulphur (IV) oxides) which could be due to Anaerobic decomposition of the waste dump.

\section{Profile 3}

These profile lies $20 \mathrm{~m}$ away from the edge of the waste dump at North/East between minor and street road. The two dominants low and high anomalous zones were delineated (Fig. 6c). The low resistivity anomaly (Dark to Light Blue) was mapped on the surface of the section stretching throughout the entire length of the traverse. With resistivity varying $\geq 1.91 \Omega \mathrm{m}$ to $7.75 \Omega \mathrm{m}$, isolated from $0.0 \mathrm{~m}$ to $12.5 \mathrm{~m}$ and continued from $17.5 \mathrm{~m}$ to $95 \mathrm{~m}$, at depths varying between $0.930 \mathrm{~m}$ to $4.76 \mathrm{~m}$ are interpreted as sand or soil saturated with leachate plume contaminants that contains dangerous pathogens, including dissolved organic and inorganic constituents. The layer of high resistivity (Green-yellow) with resistivities ranging from $15.6 \Omega \mathrm{m}$ to $63.2 \Omega \mathrm{m}$ at the depth of $2.81 \mathrm{~m}$ to $6.95 \mathrm{~m}$, sandwiched downward at the centre of the surface points between $40.0 \mathrm{~m}$ to $57.5 \mathrm{~m}$, with the depth ranging from $6.95 \mathrm{~m}$ to $14.8 \mathrm{~m}$ is identified as porous and permeable sandy layers of varying grain sizes and moisture contents. The zones colours (Red-Purple) of anomalously high resistivities between $127 \Omega \mathrm{m}$ to $\geq 256 \Omega \mathrm{m}$ at the depths of $9.38 \mathrm{~m}$ to $14.8 \mathrm{~m}$ is identified as waste dump gases (Methane, Ammonia, carbon (IV) oxides or Surphur (IV) oxides) which could be due to Anaerobic decomposition of the waste dump.

\section{Profile 4}

The profile lies 20m away from the edge of the waste dump at North/East along gas turbine right of way. The two dominants low and high anomalous zones were delineated (Fig. 6d). The low resistivity zone colours (Dark-light Blue) ranges from $0.295 \Omega \mathrm{m}$ to $2.61 \Omega \mathrm{m}$ is isolated at the top section of the profile ranging from $7.5 \mathrm{~m}$ to $39.5,52.5 \mathrm{~m}, 85 \mathrm{~m}$ to $87.5 \mathrm{~m}$ and $90 \mathrm{~m}$ to $95 \mathrm{~m}$, at the depths of $0.938 \mathrm{~m}$ to $2.81 \mathrm{~m}$ are identified as leachate plume. The (light green to yellow) colour with resistivities ranging from $7.76 \Omega \mathrm{m}$ to $68.7 \Omega \mathrm{m}$ at the depths of $0.938 \mathrm{~m}$ to $4.76 \mathrm{~m}$ with surface points ranging from $40 \mathrm{~m}$ to $60 \mathrm{~m}$ to $65 \mathrm{~m}, 77.5 \mathrm{~m}$ to $80 \mathrm{~m}, 82.5 \mathrm{~m}$ to $85 \mathrm{~m}, 87.5 \mathrm{~m}$ to $90 \mathrm{~m}$ is identified as porous and permeable sandy 
Ogbonna, V.A et al. "Impacts of Landfill on Groundwater Quality in Eligbolo-Eliozu, Obio/Akpor Local Government Area, Rivers State, Nigeria"

layers of varying grain sizes and moisture contents. While the zones colours (Red-Purple) of anomalously high resistivities between $204 \Omega \mathrm{m}$ to $607 \Omega \mathrm{m}$ with the depths of $6.96 \mathrm{~m}$ to $14.8 \mathrm{~m}$ is identified as waste gases (Methane, Ammonia, carbon (IV) oxides or Surphur (IV) oxides ) which could be due to Anaerobic decomposition of the waste dump.

\section{Profile 5}

These profile lies $15 \mathrm{~m}$ away from the edge of the waste dump at the South/West direction of the landfill, along the turbine line and dumpsite entrance. The two dominants low and high anomalous zones were delineated (Fig.6e). The low resistivity zone colours (Dark-light Blue) ranges from $125 \Omega \mathrm{m}$ to $290 \Omega \mathrm{m}$ with surface points of $20 \mathrm{~m}$ to $27.5 \mathrm{~m}$ and $35 \mathrm{~m}$ to $37.5 \mathrm{~m}$ at the depths of $0.938 \mathrm{~m}$ to $2.81 \mathrm{~m}$ is identified as leachate plume. The (light green to yellow) colour with resistivities ranging from $9.95 \Omega \mathrm{m}$ to $53.7 \Omega \mathrm{m}$ at the depths of $0.938 \mathrm{~m}$ to $476 \mathrm{~m}$ is identified as porous and permeable sandy layers of varying grain sizes and moisture contents. While the zones colours (Red-Purple) of anomalously high resistivities between $125 \Omega \mathrm{m}$ to $290 \Omega \mathrm{m}$ at the depths of $4.76 \mathrm{~m}$ down to $14.8 \mathrm{~m}$ is identified as waste gases (Methane, Ammonia, carbon (IV) oxides or Surphur (IV) oxides ) which could be due to Anaerobic decomposition of the waste dump.

Heavy Metals such as Lead $\left(\mathrm{Pb}^{+)}\right.$, Cadmium $\left(\mathrm{Cd}^{+}\right)$, Arsenic $(\mathrm{As})$, and Chromium $\left(\mathrm{Cr}^{+}\right.$were not detected in the study. Because the anaerobic degradation taking place in the landfill is characterized by waste gases such as Ammonia, $\mathrm{CO}_{2}$ and probably methane, leading to neutral $\mathrm{pH}$ and low $\mathrm{COD}$. This is as a result of low concentration of volatile acids that dwindles the growth of toxic metals whilst Ammonia continues to be released by acet-ogenic process (Heyer and Stegman, 1998).

The 2-D resistivity image result of all the profiles indicated contaminated groundwater and soil in the vicinity of the landfill by leachate and waste gases (probably $\mathrm{CO}_{2}, \mathrm{CH}_{4}, \mathrm{NH}_{4}, \mathrm{HS}_{2}$, and $\mathrm{SO}_{2}$ ), with resistivity varying from $0.180 \Omega \mathrm{m}$ to $428 \Omega \mathrm{m}$ and $125 \Omega \mathrm{m}$ to $2844 \Omega \mathrm{m}$. These dominated the lateral layer and moving towards the groundwater table at the depth of $11.9 \mathrm{~m}$ and concentrated more at deep topography along class 1 location of the sample points. The leachate plume penetrated side by side on profile 2 and the lateral layers of the landfill. Profile 3 and 5 of the resistivity values of $256 \Omega \mathrm{m}$ and $290 \Omega \mathrm{m}$ were low, due to waste gas diffusion on groundwater.

\section{CONCLUSION}

The lateral and vertical flow of waste contamination on soil and groundwater quality was examined using Wenner Array 2-D resistivity imaging. Two high dominants of leachate and gas zones were identified on profile one of 2-D resistivity imaging, two groundwater flow directions was identified, flowing downward to the southern direction of the state, from the West and East parts of the dumpsite. Leachate and gas infiltrate into the subsurface at the depth ranging from $4.91 \mathrm{~m}$ to $14.9 \mathrm{~m}$. Waste gasses such as carbon dioxide and ammonia, are dominant in the landfill, stunting the growth of toxic substances. The concentration of leachate percolates down from the dumpsite with time, and it is dominant on the soil surface than groundwater. Therefore, urgent attention in site planning, design and application of waste management regulation, with continuous monitoring and assessment of soil and groundwater quality is recommended.

The Federal government of Nigeria should establish Green Bench "Tribunal Court" as applied in Countries like India, Thailand, Netherlands, etc,. This will help in reducing and/or eliminating the environmental challenges on man and natural resources. Green Bench is a court of justice set up to adjudicate the violators of environmental laws and charged them in accordance to the prescribed law (Sharna, 2008). The Green Tribunal Act should be enacted in Nigeria to fill the gaps in the existing adjudicatory Framework. The legislation will maximize compliance through the optimal design of optimal enforcement strategies.

\section{REFERENCES}

[1] Alile O. M, Ojuh D. O, Iyoha A. and Egereonu J. C,(2011). Geoelectrical investigation and hydrochemical analysis of groundwater in a waste dump environment, Isolo, Lagos, International Journal of Engineering Research \& Technology (IJERT), 2 (11): 56 - 64

[2] Asthana D.K and Meera A, (2008). Environment, Problem and Solutions. S.Chand and CompanyLTD. New Delhi-110055, pp182-194. 
Ogbonna, V.A et al. "Impacts of Landfill on Groundwater Quality in Eligbolo-Eliozu, Obio/Akpor Local Government Area, Rivers State, Nigeria"

[3] Ehirim C.N and Itota G.O, (2013).Radiological Impact of a Municipal Solid Waste Dumpsite on Soil and Groundwater Using 2-D Resistivity Tomography and Gamma Ray Spectroscopy. The Pacific Journal of Science and Technology, 10 (2): 2329.

[4] Ehirim C.N, Ebeniro J.O and Olanegan O.P, (2009). A geophysical investigation of Solid Waste Landfill Using 2-D Resistivity Imaging and Vertical Electrical Sounding Methods in Port Harcourt Municipality, Rivers State, Nigeria. The Pacific Journal of Science and Technology, 10 (2): 1222.

[5] Heyer, K.U, and Stegman, R. (1998). Landfill Systems, Sanitary Landfilling of Solid wastes, long term problems with Leachate: Biotechnology, vol11.http://www.ifas-hamburg. journal.org/content/08050.pdf.

[6] Lawal, O (2014). Wasteful Disposition: Analysis of Municipal Household Waste Using Geodemorgraphic Classification. Waste Management and Research, 32 (2): 171 - 179.

[7] Loke, M.H. (1999). Electrical imaging Surveys for Environmental and Engineering Studies: A practical guide to 2-D and 3-D surveys. Geometrics, Sanjose, Calif, USA.

[8] Salam, A. (2010). Environmental and Health Impact of Solid Waste Disposal at Mangwaneni Dumpsite in Manzini: Swaziland, Journal of Sustainable Development in Africa.12 (7): 65-67.

[9] Sharna, R. (2008). Green courts in India: strengthening environmental governance. 4/1 Law, Environment and Development Journal, 3(5): 50 - 60

[10] UNICEF, (2010).The Environment for Children. Earth Scan Publications Ltd. London. 